\title{
Test Design of Fish Attractor to Improve Selectivity of Results on Purse Seine Ship
}

\author{
Eddy Setyo Koenhardono ${ }^{1}$, Sidratul Nugraha ${ }^{2}$ \\ (Received: 19 August 2020 / Revised: 16 March 2021 / Accepted: 17 March 2021)
}

\begin{abstract}
Indonesia is a country with abundant potential in the field of fisheries. With this abundant amount of fish, of course, many fishing methods have been developed, such as hunting or following the movement of fish and there are methods that only stay at one point, waiting for a group of fish to approach the gathering point. Fish calling devices that only stay at one point can use sound frequencies. By using the frequency of the sound, the fish will gather at the sound source produced by the fish calling tool, Fish Attractor. This study aims to determine the frequency of sound waves in fish species. The method used in this research is to make a tool that can produce sound waves with adjustable frequency, then the instrument testing will be conducted on fish ponds. Based on the design results, the fish calling device is equipped with an Arduino Uno, LCD, Potentiometer, Speaker, Power Amplifier, and Signal Module. In this Fish Attractor tool, the frequency can be set from $0 \mathrm{~Hz}-17,000 \mathrm{~Hz}$. With this adjustable sound frequency, it is expected to attract the attention of fish to get closer to the source of the sound frequency of the fish calling device.
\end{abstract}

Keywords - fish attractor, fish caller, frequency, voice.

\section{INTRODUCTION}

A an archipelago, Indonesia is a sea with many small islands and abundant potential fish resources. Based on data from the Indonesia Ministry of Marine Affairs and Ministry, 2017, the total national fishery production reached 23.26 million tons, which consisted of 6.04 million tons of capture fisheries and 17.22 tons of aquaculture. One type of fishing gear that is widely used by Indonesian Fishermen is Purse Seine.

Purse Seine is multi-species fishing gear. In fact, in many cases often found nets the size of the net in a very small Purse Seine fishing gear, so that small fish will also be caught. This is the main cause of fishing. In 1995, FAO issued a procedure for fishing activities responsible for the CCRF (Code of Conduct for Responsible Fisheries), in which one of the assessments was the selectivity of fishing gear. According to FAO (1995), selective fishing gear is a fishing gear that catches less than three species of fish [1].

One of the fishing aids that are able to catch selective fish is a fish collecting device based on sound frequency. Fishing aids that can produce certain sounds to attract fish to support the sound source. The use of this tool will be able to overcome the problems that are often experienced by the fishermen of the Purse Seine Ship in the selection of fishing areas and types of fish to be caught [2].

Based on the problem in the paragraph above, the researcher designed a fish calling device called the Fictor. This fishing gear is equipped with a potentiometer to provide the desired sound frequency

Eddy Setyo Koenhardono is with Department of Marine Engineering, Institut Teknologi Sepuluh Nopember, Surabaya, 60111, Indonesia. Email: eddy-koen@its.ac.id

Sidratul Nugraha is with Department of Marine Engineering, Institut Teknologi Sepuluh Nopember, Surabaya, 60111, Indonesia. E-mail: graha91@gmail.com and is equipped with an LCD for monitoring the resulting frequency. This Fictor is expected to be a solution for Purse Seine fishing vessels to increase catchment selectivity.

\section{A. Purse Seine}

Purse Seine or trawl ring is a fishing device from a net that is operated by circling the fish hordes to the bowl-shaped tool at the end of the fishing process. The operation of the trawl ring is to encircle the fish hordes, then the drawstring rope (Purse Seine) is pulled in from the ship to form a net-like bowl. Then the catch is transferred to the ship by using a scoop (see figure 1).

Purse Seine is a bag-shaped fishing device equipped with a ring and strap purse line located under the rope which functions to unite the bottom of the net during operations by pulling the purse line so that the net forms a pocket.

B. Sound Waves

Sound is something that results from vibration. Sound including longitudinal waves that propagate straight in all directions from the source. The conditions for sound occurrence and hearing are : (a) there is a sound source (a vibration object), (b) there is a medium (an intermediate for propagation), (c) there is a sound receiver that is near or within the range of the sound.

\section{Fish's Behavior towards Sound Waves}

Organs in fish that function as hearing devices are lateral lines (lateral linea) and labyrinthine structures. This organ responds to sound from outside through the relative motion of the fluid around the body of the fish. The lateral line is sensitive to the movement of weak water. The lateral line not only senses the subtle movements of the current reflected by an invisible barrier like coral but can also find disturbances caused by hidden prey or attacking enemies. The lateral line also helps the fish to remain in its formation. 


\section{Gillnet Caller Tool (Piknet)}

Piknet fish calling device (Fishnet Gill Caller) is a fish calling device for fishing methods with gill nets using a sound wave range between $100-1000 \mathrm{~Hz}$. In testing from this tool, the sound waves used are 100 -
$1000 \mathrm{~Hz}$, where the sound waves between $100-400 \mathrm{~Hz}$ do not attract fish to approach the instrument, while in the sound wave range between $500-1000 \mathrm{~Hz}$ the fish responds to the sound by approaching the instrument [3].

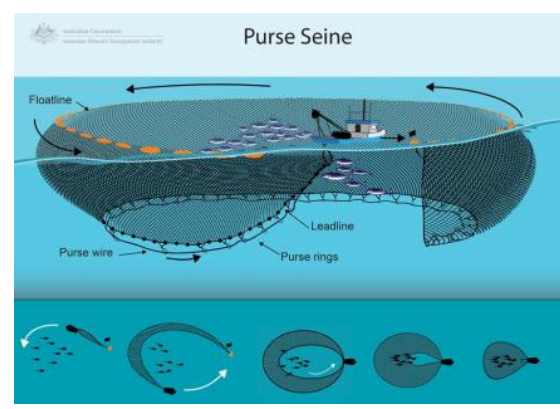

Figure. 1. Purse seine.

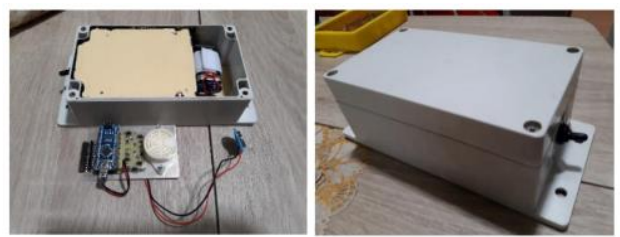

Figure. 1. Gillnet Caller Tool (Piknet) [3].

\section{E. Fish Attractor}

Fish Attractor is a tool used to call fish. Fish calling equipment in Indonesia has begun to be researched and developed by the government and the private sector. Some tools developed in principle are mimicking the sound of a collection of fish or bait.

The working principle of this tool is to make the fish attracted to the body of the net because the sound issued by the tool in a short time with a range of sound waves between $500-1000 \mathrm{~Hz}$ and will be spun and trapped. This tool can be operated throughout the day, either day or night so it is more flexible when viewed from the time of use.
The workings of the Fish Attractor are as follows: Fish Attractor will work after the battery is connected to an electronic circuit. The microcontroller will process the frequency used in accordance with the program made in the range of $0-17000 \mathrm{~Hz}$. The resulting frequency is sent to the driver to be output via the speaker. The loudspeaker will make a sound according to the frequency that is made from $0-17,000 \mathrm{~Hz}$ repeatedly, with three repetitions of the same sound at each frequency. Sounds released from the tool into the waters will propagate, where the fish that hear the sound will approach the sound source.

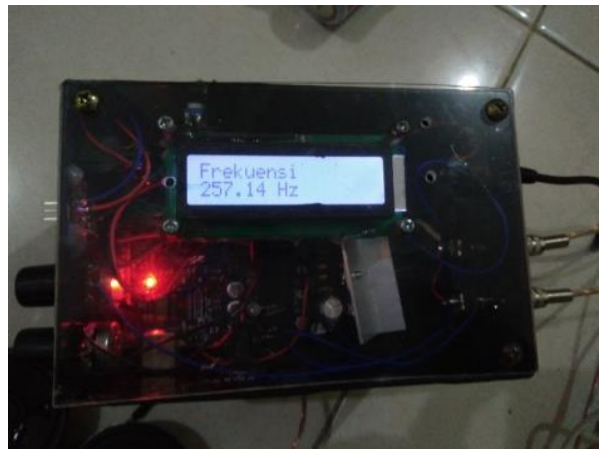

Figure. 2. Fish attractor.

\section{F. Strengths and Weaknesses of Fish Attractor}

1) Strengths

1. Fish Attractor is able to attract the attention of fish to get close to the sound source.

2. The frequency can be adjusted according to the type of fish.

3. Fish Attractor is more concise and easy to carry because it is portable.

4. Fish Attractor is equipped with an LCD screen as a frequency indicator and frequency regulator.
2) Weaknesses

1. Fish Attractor operated at sea have the potential to suffer damage to electronic components due to ocean waves.

2. Fish Attractor has not been equipped with a good waterproof system.

\section{METHOD}

A. Fish Attractor Design 
Fish Attractor is designed with a box shape. This Fish Attractor is equipped with a Micronkontroler (Arduino Uno), Graph (Light Emitting Diode) Graph, XR220,
Stereo Class D Amplifier, Battery, Adapter, and Loudspeaker.

\section{7,98}

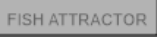

Figure. 4. Front view.

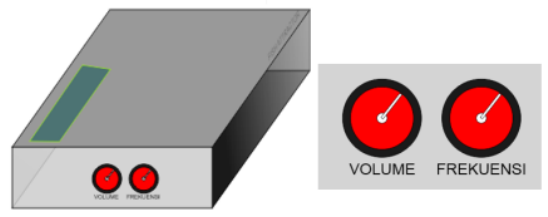

Figure. 5. Fish Attractor feature.

\section{B. PVC Pipe Pontoon}

The design of the pontoon uses PVC pipe material, L

fitting, Fitting T, and end cap. Pontoon is formed with a square shape.

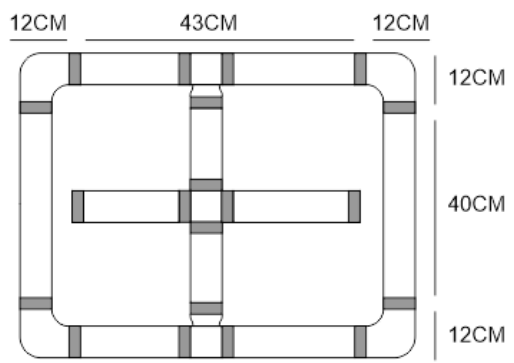

Figure. 6. PVC Pipe pontoon

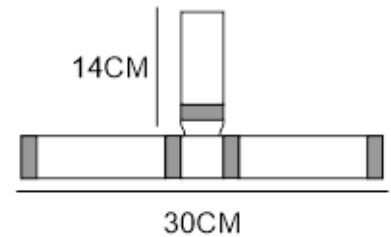

Figure. 7. Bottom.

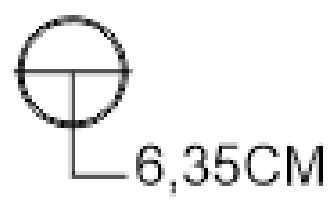

Figure. 8. Diameter.

\section{Component Procurement}

1) Arduino Uno

In this research, researchers chose Arduino Uno as a microcontroller to build a system. Arduino Uno was chosen because it has a Bootloader that functions to handle the process of entering programs from a computer into Arduino Uno, the language used to program Arduino Uno using $\mathrm{C}$ language, Arduino Uno uses a USB port (Universal Serial Bus), has facilities such as memory, pin input and output complete, and Open Source [4]. 


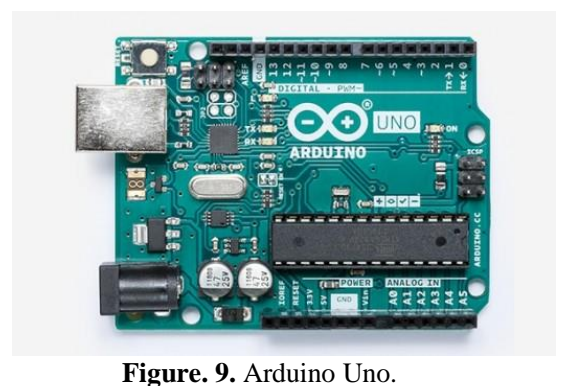

2) Relay

Relays are used to move the switch contacts and operate the LCD screen, loudspeaker, volume, and frequency.

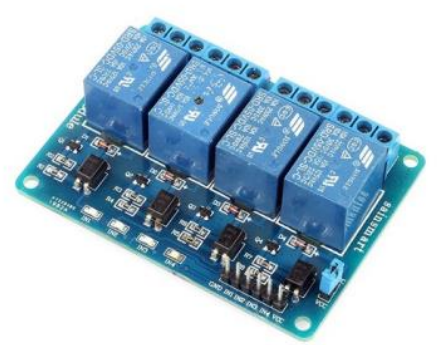

Figure. 10. Relay.

3) Battery

A battery is a device that can convert the stored chemical energy into electrical energy that can be used by an electronic device [5]. Each battery consists of a positive terminal (cathode) and the negative terminal (anode) and an electrolyte that functions as a conduit. In general, batteries consist of
2 main types, namely primary batteries that can only be used once (single-use battery), such as ZincCarbon, Alkaline, Lithium, and Silver Oxide batteries. Meanwhile, secondary batteries are rechargeable batteries, such as Nickel-Cadmium, Nickel-Metal Hydride, and Lithium-Ion batteries.

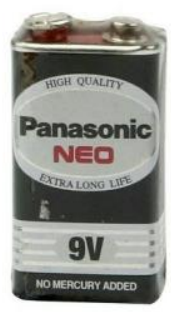

Figure. 11. Battery.

\section{4) Loudspeaker}

The loudspeaker is the last or reverse engine of the microphone. The loudspeaker carries an electrical signal and converts it back into physical vibrations to produce sound waves. Changing electric current causes the coil to move in and out. The coil motion was continued by the conus (ballot paper) which then vibrated the sound. Based on how it works can be divided into 2, namely passive loudspeakers (passive loudspeakers) are loudspeakers that do not have an amplifier (sound amplifier) in them. Meanwhile, an active loudspeaker is a loudspeaker that has an amplifier in it. 


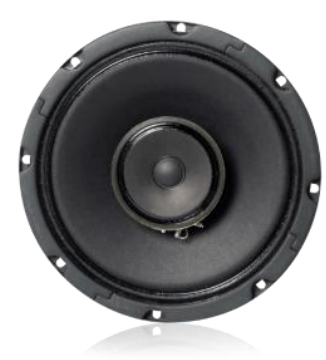

Figure. 12. Loudspeaker.

5) Adapter

An adapter is a device in the form of an electronic circuit to convert a large electric voltage into smaller electricity, or a circuit to convert alternating current (AC current) into direct current (DC current). The adapter/power supply is a core component of electronic equipment. The adapter is used to reduce AC voltage of 22 volts to small between 3 volts to 12 volts according to the needs of electronic devices. There are 2 types of adapters based on the system works, step down transformer system adapter and switching system adapter [6].

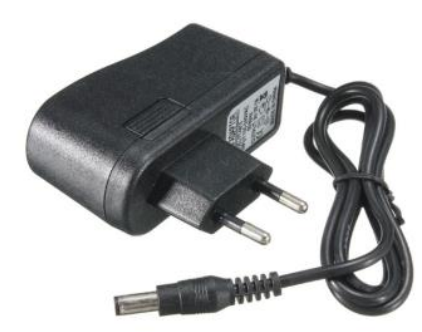

Figure. 13. Adaptor.

D. Assembly of Electronic Components for Fish Attractor

Schematic diagram of the circuit:

1) Microcontroller (Arduino Uno)

Functioning as a controller of the signal generator or signal generator.

2) Graphic LCD

Functioning as a frequency indicator display that is generated from the frequency generator.

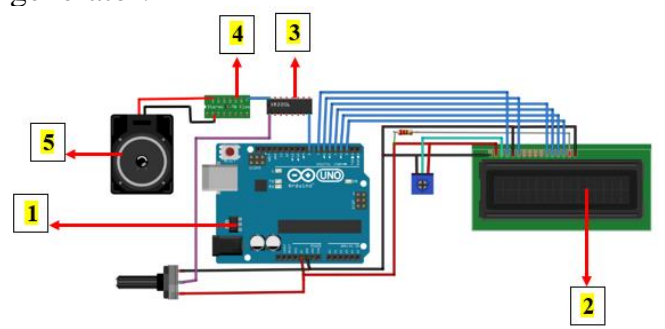

Figure. 14. Circuit of the fish attractor.

How the circuit works :

XR220 that functions as a signal generator as desired, then the signal is amplified through a Class D Amplifier to transmit signals into the water through a loudspeaker so that fish in the water can respond to these signals. The signal generator is connected to a microcontroller in order to find out what frequency is emitted into the water. The signal generator frequency is displayed in a graphic LCD display measuring 2 × 16 characters.
3) XR220

Function as a desired frequency signal generator

4) Stereo Class D Amplifier. Functioning as a loudspeaker that gets input, comes from the XR220 signal generator.

5) Loudspeaker Function to change the electrical vibration of the amplifier is converted into sound.

\section{E. Assembly of PVC Pipe Pontoon}

The Fish Attractor installation process to the PVC pipe pontoon, through the $\mathrm{T}$ fitting connection that is in the middle of the plywood and pontoon, that is by punching holes in the middle as the entry point for the loudspeaker cable. 
International Journal of Marine Engineering Innovation and Research, Vol. 6(1), Mar. 2021. 65-76 (pISSN: 2541-5972, eISSN: 2548-1479)

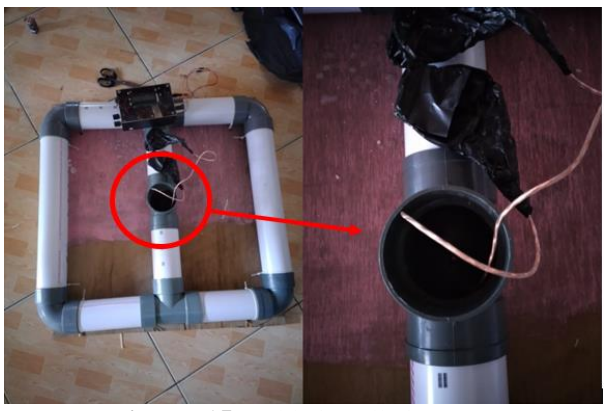

Figure. 15. Cable installation.

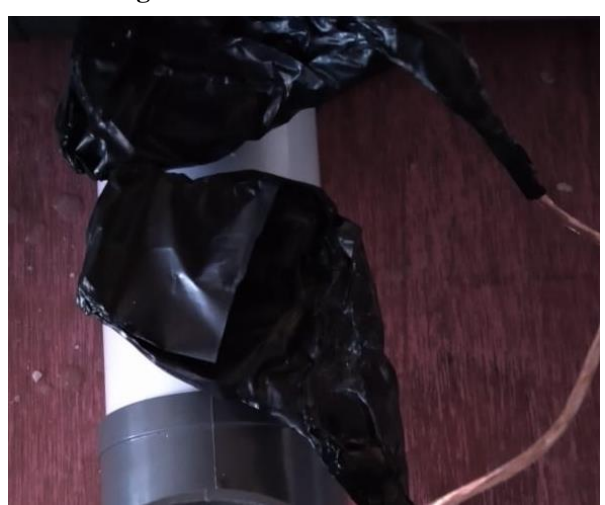

Figure. 16. Loudspeaker with plastic.

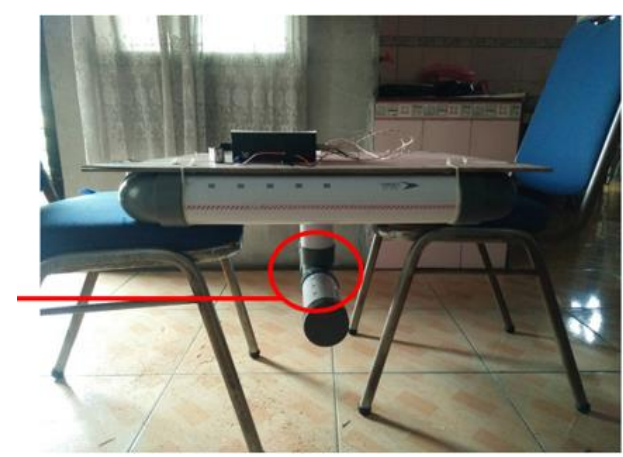

Figure. 17. Final assembly.

A. Sound Frequency Test in Water

TABLE 1.

SOUND FREQUENCY TEST

\begin{tabular}{lccc}
\hline & Frequency $($ Hz) & Distance (Meter) & Sound \\
\hline 1 & 200 & 1 & Very Clear \\
2 & 300 & 1 & Very Clear \\
3 & 500 & 1 & Very Clear \\
4 & 800 & 1 & Very Clear \\
5 & 1000 & 1 & Very Clear \\
6 & 2000 & 1 & Clear \\
7 & 3000 & 1 & Clear \\
8 & 4000 & 1 & Clear \\
9 & 5000 & 1 & Unclear \\
10 & 8000 & 1 & Unclear \\
11 & 10.000 & 1 & Unclear \\
12 & 11.000 & 1 & Not Clear \\
13 & 12.500 & 1 & Not Clear \\
14 & 13.000 & 1 & Lost \\
15 & 14.000 & 1 & Lost \\
16 & 15.000 & 1 & Lost \\
\hline
\end{tabular}




\begin{tabular}{llll}
\hline 17 & 16.000 & 1 & Lost \\
18 & 17.000 & 1 & Lost \\
\hline
\end{tabular}

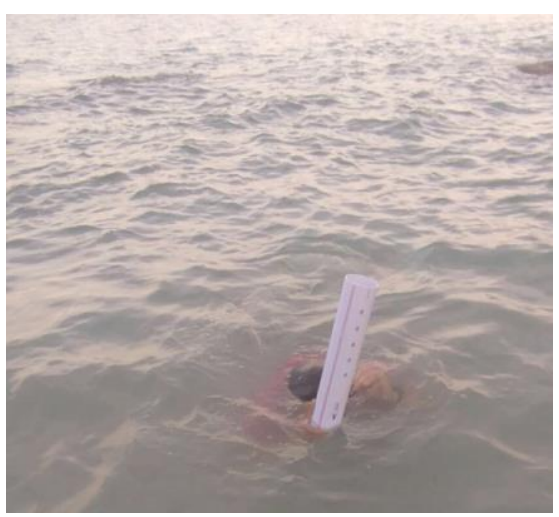

Figure. 18. Sound frequency test.

to human hearing which is very different from fish

The results of sound frequency testing conducted in hearing and sound is also influenced by water as a sound water, show that the sound is still clearly heard at frequencies of $200-4000 \mathrm{~Hz}$, the sound is less clear at frequencies $5,000-10,000 \mathrm{~Hz}$, while at frequencies $11,000-12,500 \mathrm{~Hz}$ and $13,000-17,000 \mathrm{~Hz}$, the sound is propagation media.

barely sound complete and disappear. This test is limited

\section{B. PVC Pipe Pontoon Waterproof Test}

TABLE 2.

PVC PIPE PONTOON WATERPROOF TEST

\begin{tabular}{cccc}
\hline & $\begin{array}{c}\text { Time } \\
\text { (Minute) }\end{array}$ & Yes & Waterproof \\
& & $\sqrt{ }$ & No \\
\cline { 2 - 4 } 1 & 3 & $\sqrt{ }$ & \\
2 & 5 & $\sqrt{ }$ & \\
3 & 10 & & $\sqrt{ }$ \\
4 & 15 & & $\sqrt{ }$ \\
5 & 20 & & $\sqrt{ }$ \\
6 & 25 & & $\sqrt{ }$ \\
7 & 30 & & $\sqrt{ }$ \\
8 & 35 & & $\sqrt{ }$ \\
9 & 40 & & \\
10 & 45 & & \\
\hline
\end{tabular}

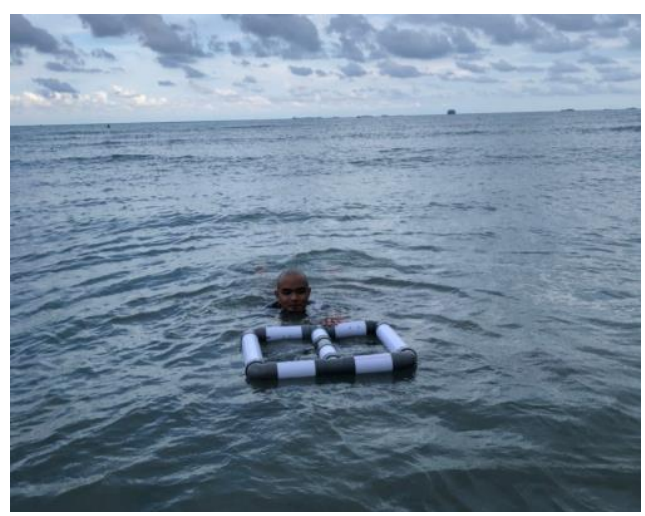

Figure. 19. Waterproof test. 


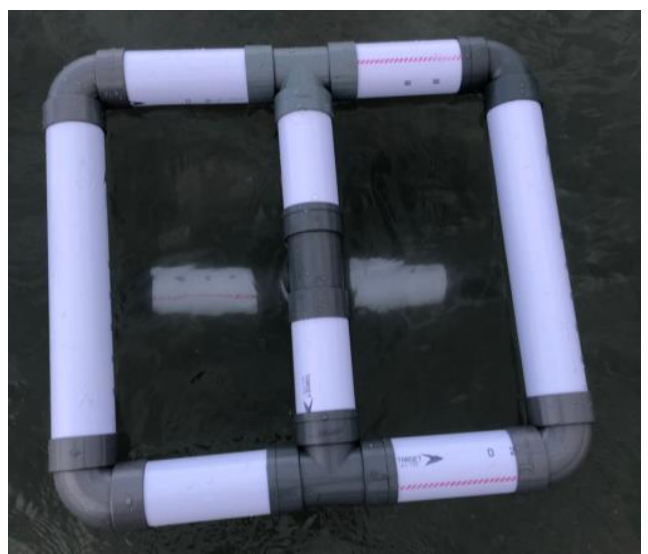

Figure. 20. PVC pipe pontoon.

The results of a waterproof test on PVC pipe pontoons indicate that the pontoon is still vulnerable to the entry of water into the PVC pipe tube. From table 2 PVC pipe pontificate has only last for 3 - 10 minutes, while in $20-45$ minutes the tube is unable to hold the water in. From the results of the analysis conducted, it appeared that water entered from the cracks of the $\mathrm{L}$ fitting and T fitting installed on the PVC pipe pontoon.
C. Test the Effect of Sound Frequency of Fish Attractor on Fish

1) First Pond

TABLE 3.

FIRST POND TEST RESULTS

\begin{tabular}{ccccc}
\hline & Frequency $(\mathbf{H z})$ & Hour $($ WIB $)$ & Time $($ Minute) & Result \\
\cline { 2 - 4 } 1 & 200 & $16.00-16.03$ & 3 & Fish Approaching \\
2 & 500 & $16.04-16.10$ & 6 & Fish Approaching \\
3 & 600 & $16.12-16.17$ & 5 & Fish Approaching \\
4 & 1000 & $16.18-16.24$ & 6 & Fish Approaching \\
5 & 1500 & $16.26-16.32$ & 6 & Fish Approaching \\
6 & 2000 & $16.33-16.42$ & 9 & Fish Away \\
7 & 3000 & $16.43-16.53$ & 10 & No Fish \\
\hline
\end{tabular}

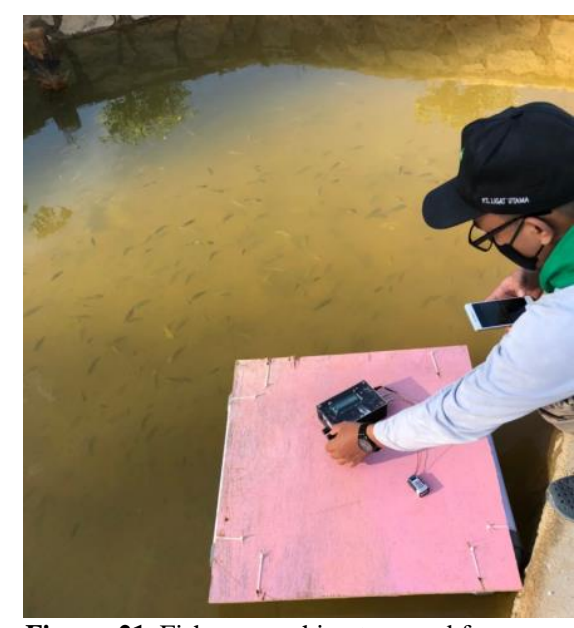

Figure. 21. Fish approaching to sound frequency $200-1500 \mathrm{~Hz}$ in the first pond. 


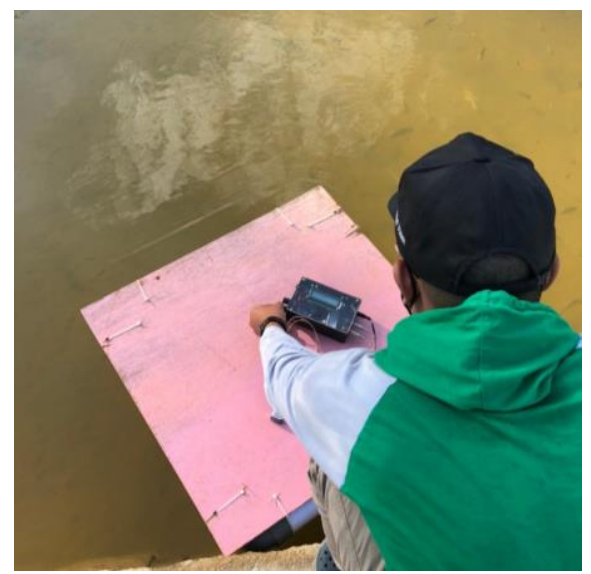

Figure 3. 1. Fish away from $2000 \mathrm{~Hz}$

sound frequency source in the first pond.

2) Second Pond

TABLE 4.

SECOND POND TEST RESULTS

\begin{tabular}{ccccc}
\hline & Frequency $(\mathbf{H z})$ & Hour $($ WIB $)$ & $\begin{array}{c}\text { Time } \\
\text { (Minute) }\end{array}$ & Result \\
\cline { 2 - 5 } 1 & 500 & $17.02-17.09$ & 7 & Fish Approaching \\
2 & 800 & $17.10-17.15$ & 5 & Fish Approaching \\
3 & 1000 & $17.16-17.25$ & 9 & Fish Approaching \\
4 & 1500 & $17.27-17.31$ & 4 & Fish Approaching \\
5 & 2000 & $17.32-17.43$ & 11 & No Fish \\
\hline
\end{tabular}

The results of testing the effect of sound frequencies on fish in 2 ponds showed a significant difference. Can be seen in the length of time of testing and movement of fish to the source of Fish Attractor sound frequency. On the first pond, at a frequency of $200-1500 \mathrm{~Hz}$, the movement of fish approaches the Fish Attractor. The fish began to move away at a frequency of $2000 \mathrm{~Hz}$ and finally, at the frequency of $3000 \mathrm{~Hz}$, no fish at all approached the sound frequency source. While on the second pond, the fish approached the sound source at a frequency of $500 \mathrm{~Hz}$ which took 7 minutes, followed by a frequency of $800 \mathrm{~Hz}$ with 5 minutes, $1000 \mathrm{~Hz}$ with 9 minutes, $1500 \mathrm{~Hz}$ with 4 minutes and the fish were not interested at all for closer to the sound source at a frequency of $2000 \mathrm{~Hz}$ with a waiting time of 11 minutes.

According to researchers, the movement of fish that approached and moved away was influenced by the size of the pond in the first pond that had a fairly small size, which is $10 \times 4$ meters and the second pond has a size of $20 \times 8$ meters. With the size of the two ponds that are different, then the sound heard by a group of fish is easier to make the fish attracted to the source of the sound frequency of the Fish Attractor on the first pond, whereas in testing on the second pond, it takes a long time to wait for the fish collection to approach the source sound frequency. Both ponds have the same type of fish, namely Nila (Oreochromis Niloticus). In one study, the majority of fish species are known to detect sounds from below $50 \mathrm{~Hz}$ to 500 or even $1500 \mathrm{~Hz}$, some species can detect sounds up to more than $3000 \mathrm{~Hz}$, while very few can detect sounds up to more than $100 \mathrm{kHz}$ [7].

\section{Test the Ability of the Tool to Attract the Attention of with Various Conditions \\ 1) Off Condition}

TABLE 5.

OFF CONDITION

\begin{tabular}{cccc}
\hline & Condition & $\begin{array}{c}\text { Time } \\
\text { (Minute) }\end{array}$ & Result \\
\cline { 2 - 4 } 1 & Off & 2 & No Fish \\
2 & Off & 6 & No Fish \\
3 & Off & 8 & 2 Fish \\
4 & Off & 10 & Approaching \\
5 & Off & 12 & Fish Away \\
6 & Off & 14 & No Fish \\
\hline
\end{tabular}


2) On Condition

TABLE 6.

ON CONDITION

\begin{tabular}{cccc}
\hline No & Condition & $\begin{array}{c}\text { Time } \\
\text { (Minute) }\end{array}$ & Result \\
\hline 1 & On & 2 & $\begin{array}{c}\text { The fish that come close to the tool are } \\
2 \text { (two) and last for 2 minutes }\end{array}$ \\
& & & The fish that come close to the tool is 1 \\
2 & On & 5 & (one) and last for 1 minute \\
3 & On & 6 & No Fish \\
4 & On & 8 & No Fish \\
5 & On & 10 & No Fish \\
\hline
\end{tabular}

3) On and Off Condition

TABLE 7.

ON AND OFF CONDITION TEST

\begin{tabular}{|c|c|c|c|c|c|}
\hline & \multicolumn{2}{|c|}{ Condition } & \multicolumn{3}{|c|}{ Condition } \\
\hline & Off & Result & On & Result & \\
\hline 1 & $\begin{array}{l}\text { The tool is placed on } \\
\text { the pond in off } \\
\text { condition for } 2 \text { (two) } \\
\text { minutes }\end{array}$ & No Fish & $\begin{array}{l}\text { Then the device is turned on } \\
\text { for } 2 \text { (two) minutes }\end{array}$ & No Fish & \\
\hline 2 & $\begin{array}{l}\text { The tool is placed on } \\
\text { the pond in off } \\
\text { condition for } 5 \text { (five) } \\
\text { minutes }\end{array}$ & $\begin{array}{l}2 \text { (two) fish } \\
\text { approaching }\end{array}$ & $\begin{array}{l}\text { Then the device is turned on } \\
\text { for } 5 \text { (five) minutes }\end{array}$ & $\begin{array}{l}1 \quad \text { (one) } \\
\text { approaching }\end{array}$ & fish \\
\hline 3 & $\begin{array}{l}\text { The tool is placed on } \\
\text { the pond in off } \\
\text { condition for } 7 \text { (seven) } \\
\text { minutes }\end{array}$ & No Fish & $\begin{array}{l}\text { Then the device is turned on } \\
\text { for } 7 \text { (seven) minutes }\end{array}$ & $\begin{array}{l}1 \quad \text { (one) } \\
\text { approaching }\end{array}$ & fish \\
\hline
\end{tabular}

Based on 3 (three) results of experiments that have been done by researchers. Researchers draw little conclusions that there is potential for fish to be attracted to the color of white PVC pipes. It was mentioned that in his research in the conclusions section, the fish were more attracted to white and green compared to blue and red. The most preferred color is the white color [8].

TABLE 8.

15 MINUTES TEST

\begin{tabular}{ccccc}
\hline No. & $\begin{array}{c}\text { Frequency } \\
(\text { Hz) }\end{array}$ & $\begin{array}{c}\text { Time } \\
\text { (Minutes) }\end{array}$ & Population & Fish Approaching \\
\hline 1 & 200 & 15 & 150 & 13 \\
2 & 500 & 15 & 150 & 31 \\
3 & 600 & 15 & 150 & 25 \\
4 & 1000 & 15 & 150 & 15 \\
5 & 1500 & 15 & 150 & 20 \\
\hline
\end{tabular}

\section{F. Sound Frequency Test for 30 Minutes}

In testing the sound frequency for 30 minutes using a

frequency of $200-1500 \mathrm{~Hz}$, the frequency used is the

\footnotetext{
TABLE 9.
}

30 MINUTES TEST

\begin{tabular}{ccccc}
\hline No. & $\begin{array}{c}\text { Fequency } \\
(\text { Hz) }\end{array}$ & $\begin{array}{c}\text { Time } \\
\text { (Minutes) }\end{array}$ & Population & $\begin{array}{c}\text { Fish } \\
\text { Approaching }\end{array}$ \\
\hline
\end{tabular}
Attractor on Nila fish.

\section{E. Sound Frequency Test for 15 Minutes}

In testing the sound frequency for 15 minutes using a frequency of $200-1500 \mathrm{~Hz}$, the frequency used is the result of testing that has been done by researchers in Table 8 Test of the Sound Frequency Effect of the Fish Attractor on Nila fish.

result of testing that has been done by researchers in Table 9 Test of the Sound Frequency Effect of the Fish 


\begin{tabular}{lcccc}
\hline 1 & 200 & 30 & 150 & 18 \\
2 & 500 & 30 & 150 & 37 \\
3 & 600 & 30 & 150 & 26 \\
4 & 1000 & 30 & 150 & 15 \\
5 & 1500 & 30 & 150 & 14 \\
\hline
\end{tabular}

\section{G. Sound Frequency Test for 45 Minutes}

In testing the sound frequency for 45 minutes using a frequency of $200-1500 \mathrm{~Hz}$, the frequency used is the result of testing that has been done by researchers in Table 10 Test of the Sound Frequency Effect of the Fish Attractor on Nila fish.

TABLE 10.

45 MINUTES TEST

\begin{tabular}{ccccc}
\hline No. & $\begin{array}{c}\text { Frequency } \\
\text { (Hz) }\end{array}$ & $\begin{array}{c}\text { Time } \\
\text { (Minutes) }\end{array}$ & Population & $\begin{array}{c}\text { Fish } \\
\text { Approaching }\end{array}$ \\
\hline 1 & 200 & 45 & 150 & 20 \\
2 & 500 & 45 & 150 & 43 \\
3 & 600 & 45 & 150 & 31 \\
4 & 1000 & 45 & 150 & 21 \\
5 & 1500 & 45 & 150 & 19 \\
\hline
\end{tabular}

\section{H. Sound Frequency Test for 70 Minutes}

In testing the sound frequency for 70 minutes using a frequency of $200-1500 \mathrm{~Hz}$, the frequency used is the

result of testing that has been done by researchers in Table 11 Test of the Sound Frequency Effect of the Fish Attractor on Nila fish.

TABLE 11.

70 MINUTES TEST

\begin{tabular}{ccccc}
\hline No. & $\begin{array}{c}\text { Frequency } \\
\text { (Hz) }\end{array}$ & $\begin{array}{c}\text { Time } \\
\text { (Minutes) }\end{array}$ & Population & $\begin{array}{c}\text { Fish } \\
\text { Approaching }\end{array}$ \\
\hline 1 & 200 & 70 & 150 & 28 \\
2 & 500 & 70 & 150 & 63 \\
3 & 600 & 70 & 150 & 42 \\
4 & 1000 & 70 & 150 & 29 \\
5 & 1500 & 70 & 150 & 23 \\
\hline
\end{tabular}

result of testing that has been done by researchers in

\section{Sound Frequency Test for 90 Minutes}

In testing the sound frequency for 30 minutes using a frequency of $200-1500 \mathrm{~Hz}$, the frequency used is the
Table 12 Test of the Sound Frequency Effect of the Fish Attractor on Nila fish.

TABLE 12.

90 MINUTES TEST

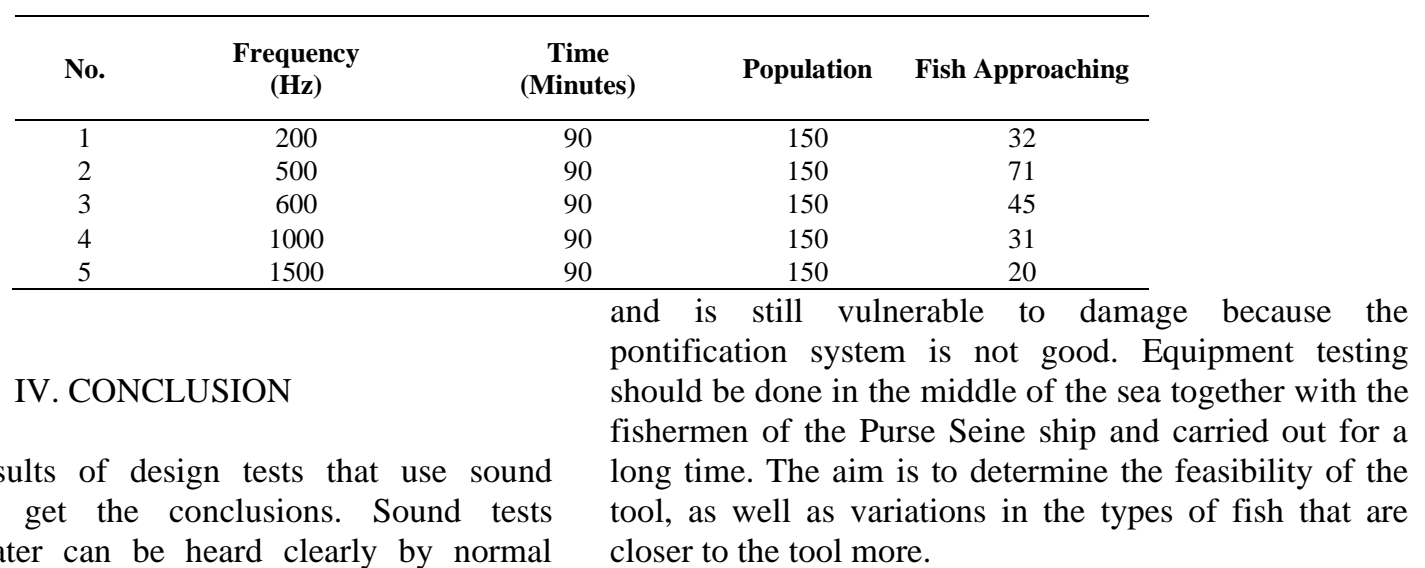

\section{ACKNOWLEDGEMENTS}

$\mathrm{Hz}$. The results of tests conducted on fish ponds have shown some positive results. The response of fish to the sound emitted in the water can attract the attention of fish to get close to the sound source. Based on the test results, fish are interested in frequencies of $200-1500$ Hz. Sound testing should be done in the middle of the sea, to find out how far the sound can be heard in the middle of unstable sea wave conditions. Design of the

Pontoon The PVC pipe used still looks very simple

Thanks to Mr. Setya Budi and MEAS laboratory friends who helped me complete my final project.

\section{REFERENCES}

[1] A. Rambun, P. Sunarto, and I. Nurruhwati, "Selektivitas Alat Tangkap Purse Seine Di Pangkalan Pendaratan Ikan (Ppi) Muara Angke Jakarta," J. Perikan. Kelaut., vol. VII, no. 2, pp. 97-102, 
2016.

[2] S. Sugiyanto, J. D. Setiawan, F. Nugraha, and R. W. Yuwana, "Dasar-Dasar Perancangan Alat Pemanggil Ikan," Rotasi, vol. 21, no. 2 , p. $115,2019$.

[3] N. Rosana, "Penentuan Gelombang Bunyi Dalam Pembuatan Alat," pp. 18-22, 2017.

[4] F. Djuandi, "Pengenalan Arduino," E-book. www. tobuku, pp. 1$24,2011$.

[5] D. Kho, "Pengertian Baterai dan Jenis-jenis Baterai," Teknikelektronika.Com. 2015.

[6] V. DAMAYANTI, "Pengertian dan Manfaat Adaptor/Power Suplay," 2017.

[7] L. Armundsen and M. Landrø, "Fish hear a great deal," Technology, pp. 37-41, 2011.

[8] F. Urbasa, F. E. Kaparang, and H. J. Kumajas, "Studi ketertarikan ikan di keramba jaring apung terhadap warna cahaya lampu di perairan Sindulang I, Kecamatan Tuminting, Kota Manado,” J. Ilmu Dan Teknol. Perikan. Tangkap, vol. 2, pp. 39-43, 2015. 